\section{Ramme 1}

\section{Diagnostiske kriterier ved Kawasakis sykdom}

Feber i mer enn fem dager og tilstedeværelse av fire av følgende kriterier:

Cervikal lymfadenopati

Forandringer i oropharynx: såre, sprukne lepper; papillær hypertofi på tungen, injisert pharynx

Polymorft hudutslett

Bilateral konjunktival injeksjon

Ekstremitetsforandringer med rubor

og ødem med etter hvert deskvamasjon av hud på hender og føtter

7-14 dager og en subakutt fase på 10-20 dager (2). Ubehandlet sykdom tilheler vanligvis spontant etter fire til seks uker (7). Risikoen for komplikasjoner i form av koronart aneurisme er ved ubehandlet sykdom $20-25 \%$ hos barn og 5\% hos voksne (2). Målet med behandlingen er å dempe den akutte inflammasjonen og forebygge alvorlige kardiovaskulære komplikasjoner. Behandling med immunglobulin intravenøst er godt dokumentert hos barn. Standardbehandlingen i dag er én enkelt dose gammaglobulin $(2 \mathrm{~g} / \mathrm{kg})$ i akuttfasen, etterfulgt av en lav dose acetylsalisylsyre over et par måneder. Argumenter for ikke å igangsette behandling er kostnadene ved bruk av medisinen, risiko for transfusjonsreaksjon og det at vaksinering med levende virus må utsettes $\mathrm{i}$ inntil seks måneder (7).

Kawasakis sykdom er en sjelden tilstand hos voksne. Totalt er det beskrevet i underkant av 60 tilfeller i litteraturen (3). Av disse var ni personer hivpositive. I Europa er det registrert 25 tilfeller, de øvrige i USA (25 personer), i Asia (fem) og i Afrika (to). Disse pasientene hadde diagnosen Kawasakis sykdom (feber pluss fire av fem kliniske symptomer) eller inkomplett Kawasakis sykdom. I de rapporterte tilfellene hos voksne er det ofte adenopati og økte leververdier. I tillegg er trombocytose, icterus og artralgi hyppig forekommende i subakuttfasen (4). Det er også beskrevet tilfeller av Kawasakis sykdom med galleblærehydrops, anemi, forhøyet senkningsreaksjon og forhøyet CRPnivå, slik som hos vår pasient (3).

Av de 57 tilfellene som var rapportert frem til 2005 , hadde 18 pasienter fått intravenøs behandling med immunglobulin. Denne behandlingen ble gitt med bakgrunn i retningslinjer for barn, søk i litteraturen og andre publiserte artikler (3), da det ikke foreligger kunnskapsbasert behandling for voksne. Det er ikke rapportert om dødsfall hos voksne i forbindelse med sykdommen (2). Så langt er Kawasakis sykdom i Norge bare beskrevet hos barn (8). Aktuelle differensialdiagnoser hos voksne er toksisk sjokk-syndrom, hypersensitivitetsreaksjon på medikamenter og viral eller vektorbåren infeksjonssykdom.

Grunnlaget for å sette diagnosen Kawasakis sykdom hos vår pasient var kliniske funn, radiologiske undersøkelser, kliniskkjemiske prøver og komplett negativ bakteriell og viral agens- og antistoffpåvisning. Alle de immunologiske prøvene var også innenfor referanseområdet. Pasienten hadde i akuttfasen høy senkningsreaksjon og høyt CRP-nivå, lettgradig anemi, økning av transaminaser og tegn til kolestase. Radiologisk var det galleblærehydrops. I subakuttfasen utviklet han trombocytose. Det er ikke dokumentert hvor lenge behandling med lavdose acetylsalisylsyre bør kontinueres hos voksne. Med utgangspunkt i tidligere publiserte kasuistikker valgte vi en behand- lingsvarighet på to måneder med Albyl E 75 mg daglig (3).

Forekomsten av Kawasakis sykdom hos voksne er lav, og det har derfor ikke vært mulig å gjennomføre prospektive randomiserte studier for valg av behandling. Tilgjengelig litteratur om Kawasakis sykdom hos voksne er begrenset. Gjennomgang av litteraturen viser at behandlingsstrategiene er kunnskapsbasert medisin på laveste nivå (nivå 3). Det gir ikke noe grunnlag for å konkludere hvorvidt pasienter rutinemessig bør ha behandling med intravenøs immunglobulin.

Pasienten har gitt samtykke til at artikkelen blir publisert.

Oppgitte interessekonflikter: Ingen

\section{Litteratur}

1. Moxness MH, Bergh K. Tularemi som differensialdiagnose ved tumor colli. Tidsskr Nor Lægeforen 2006; 126: 1055-7.

2. Wolff AE, Hansen KE, Zakowski L et al. Acute Kawasaki disease: not just for kids. J Gen Intern Med 2007: 22: 681-4

3. Sève P, Stankovic K, Smail A et al. Adult Kawasaki disease: report of two cases and literature review. Semin Arthritis Rheum 2005; 34: 785-92.

4. Dauphin C, Motreff P. Souteyrand G et al. La maladie de Kawasaki est aussi une maladie de l'adulte. Arch Mal Coeur Vaiss 2007; 100: 439-47.

5. Hoffman TU, Paerregaard A. Kawasakis syndrom en infektionssygdom? Ugeskr Læger 2002; 164: 5934-6.

6. Hansen SK, Buhl MR. Kawasaki-syndrom hos en voksen. Ugeskr Læger 1998; 160: 1807-8.

7. Rozo JC, Jefferies JL, Eidem BW el al. Kawasaki disease in the adult: a case report and review of the literature. Tex Heart Inst J 2004: 31: 160-4.

8. Klevberg S, Farstad T, Perminow KV. Forekomst av Kawasakis sykdom. Tidsskr Nor Lægeforen 2004; 124: 1774-5.

Manuskriptet ble mottatt 16.3. 2009 og godkjent 25.2. 2010. Medisinsk redaktør Are Brean.

\title{
Alvorlig immunreaksjon uten mikrober
}

Kawasakis sykdom har ukjent årsak. En kraftig immunrespons genereres i personer som sannsynligvis er genetisk disponert for tilstanden. Sykdommen rammer først og fremst barn, men er beskrevet hos i alt 81 voksne (1). Immunresponsen er knyttet til vaskulitt i mellomstore arterier og gir symptomer fra en rekke organer. Det er først og fremst immunrespons og inflammasjon i koronararteriene som gir varig organaffeksjon i form av utvikling av aneurismer eller stenoser, med koronar iskemi som følge. Immunologisk er Kawasaksi sykdom interessant både med tanke på patofysiologien og med tanke på behandlingseffekten av intravenøst gammaglobulin.

Sykdommen er beskrevet som en reaksjon på en mikrobiell stimulering. Det har vært mange forslag på hvilke mikroorganismer som kan utløse Kawasakis sykdom, men ingen er vist å kunne utløse sykdommen. Det kan påvises inflammasjon i middels store arterier med antistoffer av IgM- og IgG-klasse som reagerer med antigener på endotelcellene. Det er også påvist IgA-produserende plasmaceller subendotelialt (2).

I akuttfasen er pasientenes symptomer dominert av feber, utslett, leveraffeksjon, lymfadenopati. Analyser av blodet viser forhøyet CRP-nivå, lavt albuminnivå, middels leukocytose og trombocytopeni. Bildet gjenspeiler aktivering av det medfødte immunforsvaret - med makrofagaktivering og produksjon av proinflammatoriske cytokiner slik som interleukin-1 (IL), IL-6, tumornekrosefaktor $\alpha$ og granulocytt-/monocyttkolonistimulerende faktor. Det spesifikke immunforsvaret igangsettes med aktivering av T-celler og B-celler som produserer antiendotelcelle-IgM og -IgG. Disse antistoffene kan aktivere komplement, og aktivering av komplement på endotelcelleoverfla- 
ten kan føre til lysering av endotelcellene ved hjelp av det terminale komplementkomplekset. I komplementaktivering dannes proinflammatoriske aktiveringsprodukter. Antigenpresentasjon for naive T-celler resulterer i aktivering av CD4-positive T-celler og CD8-positive T-celler, som fører til henholdsvis ytterligere aktivering av makrofager og til cytotoksisitet. Vanligvis reguleres aktiveringsprosessen av regulatoriske antigenspesifikke T-celler, men ved Kawasakis sykdom er det vist at pasientene har redusert antall regulatoriske T-celler (2).

Det er usikkert hvilken rolle IgA har i patofysiologien ved Kawasakis sykdom (3). Et tilfelle av sykdommen er beskrevet hos en pasient med IgA-mangel (4). Forekomsten av IgA-produserende plasmaceller hos de fleste av pasientene støtter teorien om en antigendrevet prosess.

Kawasaksi sykdom behandles vanligvis med store doser intravenøst immunglobulin ( $2 \mathrm{~g} / \mathrm{kg}$ i én dose). Det er angitt at effekten er best hvis behandlingen igangsettes tidlig $i$ forløpet. Dette skal ha god innvirkning på affeksjonen av koronararteriene, men ettersom sykdommen er sjelden, er det vanskelig å gjennomføre randomiserte studier av behandlingen. En rekke mekanismer for effekten av immunglobulinbehandlingen er diskutert, så som modulering av endotelcellene slik at de inflammatoriske signalene dempes, nedregulering av adhesjonsmolekyler, antiidiotypiske antistoffer som nøytraliserer antiendotelantistoffene, Fc-reseptorblokade, redusert aktivering av makrofager og stimulering av T-celleregulatorisk aktivitet. Symptomene forsvinner spontant hos pasienter som ikke blir behandlet.

Kawasakis sykdom er et eksempel på en tilstand der tilsynelatende dårlig regulert immunrespons gir til dels alvorlige symptomer hos pasientene. Immunresponsen er rettet mot antigener på endotelceller spesielt i mellomstore arterier; en type 2-hypersensitivitetsreaksjon. Behandling med immunglobulin i store doser er rapportert å ha effekt. Tilstanden må mistenkes hos barn og voksne med symptomer på akutt inflammasjon der mikrobiell patogenese er utelukket.

\section{Anne Husebekk}

anne.husebekk@unn.no

Universitetssykehuset Nord-Norge

9038 Troms $\varnothing$

Oppgitte interessekonflikter: Ingen

\section{Litteratur}

1. Gomard-Mennesson E, Landron C, Dauphin C et al. Kawasaki disease in adults. Report of 10 cases. Medicine 2010: 89: 149-58.

2. Galeotti C, Bayry J, Kone-Paut I et al. Kawasaki disease: aetiopathogenesis and therapeutic utility of intravenous immunoglobulin. Autoimmun Rev 2010; 9: 441-48.

3. Rowley A, Shulman ST, Garcia FL et al. Cloning of arterial IgA response during Kawasaki disease. J Immunol 2005; 175: 8386-91.

4. Nishikawa T, Nomura Y, Kono Y et al. Selective IgA deficiency complicated with Kawasaki syndrome. Pediatr Int 2008; 50: 816-8.

Manuskriptet ble mottatt 6.7. 2010 og godkjent 27.7. 2010. Medisinsk redaktør Are Brean. 